\title{
Response of seabirds to thermal boundaries in the tropical Pacific: the thermocline versus the Equatorial Front
}

\author{
Larry B. Spear ${ }^{1, *}$, Lisa T. Ballance ${ }^{2}$, David G. Ainley ${ }^{1}$ \\ ${ }^{1}$ H. T. Harvey \& Associates, 3150 Almaden Expressway, Suite 145, San José, California 95118, USA \\ ${ }^{2}$ Ecology Program, National Oceanic and Atmospheric Administration/National Marine Fisheries Service, \\ Southwest Fisheries Science Center, 8604 La Jolla Shores Drive, La Jolla, California 92037, USA
}

\begin{abstract}
Our 10 yr study is the first to associate seabirds with oceanic boundaries, or fronts, in tropical oceans. It addresses the semi-permanent Equatorial Front, hereafter 'front', a vertical boundary lying between the South Equatorial Current (SEC) and North Equatorial Countercurrent (NECC) in the eastern tropical Pacific (ETP). We also consider the subsurface, horizontal thermal boundary created by the thermocline. Our study area included the front and the north and south boundaries of the SEC and NECC respectively, between 100 and $145^{\circ} \mathrm{W}$. Our data were based on 45 north-south crossings of this area. The intensity of the front differed with season and phase of the El Niño Southern Oscillation (ENSO). Densities of planktivorous seabirds, higher at the front than in the SEC or NECC, increased with front intensity (i.e., during autumn/La Niña). Densities of piscivorous seabirds were unaffected by the front, but were related to depth and intensity of the thermocline. Piscivore densities were highest in the NECC, and higher during spring than autumn. Furthermore, they were higher in the western part of the study area, i.e., when and where the thermocline was deepest and most stratified. We suggest that the difference in patterns observed for the tropical planktivorous versus piscivorous seabirds reflects processes that affect the distribution and availability of their respective prey. Zooplankton are concentrated in the surface layer by physical processes that structure the front. Prey fish, on the other hand, are made available by foraging tuna, which drive them to the ocean surface. As a result, the distribution of the piscivorous seabirds is closely tied to that of schooling surface-feeding tunas, that are most abundant in the NECC. Other studies have shown that tunas spend most of their time near the thermocline. We suggest that this, along with the patterns observed among the piscivorous seabirds, indicate that the tuna's prey aggregate near the thermocline. Specifically, most tropical squid and small fishes perform vertical movements to the surface at night. A deeper thermocline, such as that of the NECC, is likely to be attractive to these animals for hiding during the day (when the tuna and birds forage) because of the lack of light at depth, and because of the enriched $\mathrm{O}_{2}$ content of the cold-water layer lying immediately below the warmer surface layer. Hence, by searching on a horizontal plane near the boundary created by a deep, well stratified thermal structure, schooling tuna, and thus piscivorous seabirds, are likely to find concentrations of prey more readily than equally abundant prey dispersed throughout a less stratified water column.
\end{abstract}

KEY WORDS: Seabird · Planktivore - Piscivore · Equatorial Front · Thermocline - Tropical Pacific · Southern Oscillation

Resale or republication not permitted without written consent of the publisher

\section{INTRODUCTION}

Ocean 'fronts' are regions with marked horizontal gradients in thermodynamic variables such as temperature, density, or velocity (reviewed in Owen 1981).
Generally of coarse-scale (width $=1$ to $100 \mathrm{~km}$ ) in the open ocean, fronts are also usually characterized by less marked vertical thermal gradients (i.e., lacking a stratified thermocline), by enhanced vertical circulation of cooler, subsurface water and nutrients 
(cf Woods et al. 1977, Owen 1981), and by concentrations of marine organisms (e.g. Olson \& Backus 1985, Hunt \& Schneider 1987, Schneider 1990, Franks 1992).

Seabird abundance and distribution are affected strongly by fronts (see above references and Ashmole 1971, Brown 1980, Hunt 1991a,b, Follestad 1990, Harrison et al. 1990, Hunt \& Harrison 1990, Schneider et al. 1990, Veit \& Hunt 1992, Veit 1995, Hunt et al. 1996, Pakhomov \& McQuaid 1996). Seabirds respond especially to strong fronts (Schneider et al. 1987, Hunt et al. 1990, Elphick \& Hunt 1993), although spatial and temporal predictability may be as important as gradient strength (Hunt 1990).

Fronts are important determinants of prey capture (see reviews by Hunt 1990, Schneider 1990). Two hypotheses have been proposed to account for this: (1) frontal zones enhance primary production, which in turn increases prey supply, and (2) frontal zones concentrate prey into exploitable patches. Results are generally consistent with the second hypothesis (Schneider 1990), although their relative importance differs with spatial scale of investigation and region of the world's oceans (review by Hunt 1990). In the open ocean, locations of prey aggregations are unpredictable, and this has important consequences for prey acquisition by seabirds. In contrast, in continental shelf systems, topographically fixed features create physical ocean gradients in predictable locations.

The association between seabirds and fronts has been documented on numerous occasions in polar waters including the Southern Ocean, Bering Sea, and North Atlantic Ocean (cf, Schneider 1982, Brown \& Gaskin 1988, Hunt 1990, Veit 1995), the California boundary current system (Briggs et al. 1987, Hoefer 2000, Oedekoven et al. 2001), and subtropical waters of the Gulf Stream (Haney \& McGillivary 1985). Yet, no studies have focused specifically on this relationship in tropical oceans (Hunt 1990, Ballance \& Pitman 1999), despite the immense size of this zone and the physical structuring present (cf Wyrtki 1966).

Here, we used at-sea surveys in the eastern tropical Pacific to investigate seabird associations with the Equatorial Front (Fig. 1), and the north and south regions of the 2 current systems between which the front lies (the South Equatorial Current and North Equatorial Countercurrent). The geographic location and strength of these currents, and consequently that of the front, differs markedly with season and year (Wyrtki 1966, Reilly 1990, Fiedler et al. 1991, Reilly \& Fiedler 1994) during different phases of the El Niño Southern Oscillation. We also consider seabird associations relative to the subsurface thermal gradients of the thermocline. Thermocline characteristics also differ considerably among the SEC, NECC, and the front (Wyrtki 1966, present study). Here we examine and compare patterns of distribution and abundance in 2 feeding guilds of open-ocean seabirds, planktivores and piscivores, in relation to temporal and spatial variation in the intensity of the front and thermocline.

\section{STUDY AREA AND METHODS}

Oceanographic variables and seabird surveys. In the equatorial Pacific, easterly tradewinds and Earth's rotation combine to drive surface currents of the SEC away from the Equator (Flament et al. 1996). The front forms to the north of the SEC where the latter meets the NECC (the SEC and NECC flow west and east, respectively). Depending on season and year, the front is located somewhere between 2 and $5^{\circ} \mathrm{N}$, and differs in width from east to west; it is most developed in the eastern Pacific (Wyrtki 1966, Fiedler et al. 1991). The 2 basin-scale current systems to the north and south are characterized by sea-surface temperature an salinity, thermocline structure, and phytoplankton content (Wyrtki 1966, Fiedler et al. 1991). Specifically, the SEC usually has lower sea-surface temperature (SST), higher salinity and chlorophyll a content, and a shallower, less-stratified thermocline.

We observed seabirds and monitored oceanographic conditions from research vessels during 45 crossings of the front, including 3 to 8 crossings during spring and autumn of each year from autumn 1983 to autumn 1991, and once in autumn 1998. Crossings were made between 100 and $145^{\circ} \mathrm{W}$. The seabird data reported herein are from 28 of the 45 crossings. Seabird data from the remaining 17 crossings were excluded either because surveys were not conducted contiguously within waters of the SEC or NECC, or because no front was detected (see next paragraph).

We recognized the front based on changes in seasurface temperature (SST). SST in the NECC is up to $5^{\circ} \mathrm{C}$ warmer than in the SEC, depending on season, year, and longitude (Wyrtki 1966, present study). Therefore, we defined the front as the section of latitude where SST changed by $2^{\circ} \mathrm{C}$. Specifically, moving south to north, SST at the Equator increased only slightly to latitudes of 1 to $2^{\circ} \mathrm{N}$, where it usually began to change rapidly. The latitude where this more rapid change began (i.e., positive inflection in SST as a function of latitude) was considered as the southern boundary of the front, and the latitude where the SST was $2{ }^{\circ} \mathrm{C}$ warmer than that at the southern boundary was considered as the northern boundary. We considered the front to be 'absent' if the temperature gradient between the SEC and NECC was $<2{ }^{\circ} \mathrm{C}$.

For the purpose of this study, the 'SEC boundary waters' were considered as those from the beginning of the front to $2^{\circ}$ latitude south of it. East to west, these 
temperature $\left({ }^{\circ} \mathrm{C}\right)$

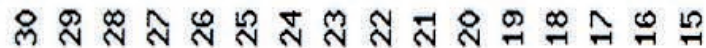

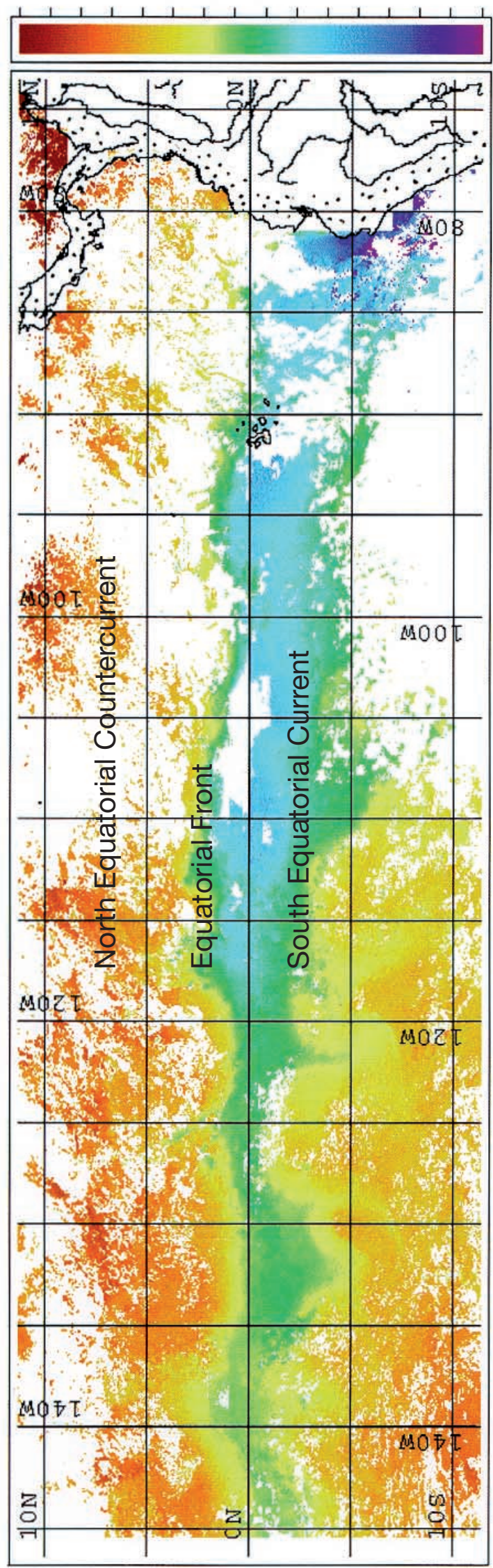

Fig. 1. Satellite image of the eastern tropical Pacific during the strong La Niña in October 1998, showing locations of current systems. Study area stretches approximately from the Equator to $7^{\circ} \mathrm{N}$ and from 100 to $145^{\circ} \mathrm{W}$. Image is a composite from multiple satellite passes, resulting in less-than real-time distinctness and location of the temperature profile due to the strong east-to-west movement of the South Equatorial Current during La Niña

surveys were within $2^{\circ}$ longitude of that line surveyed when crossing the front. Similarly, surveys of the 'NECC boundary waters' were those from the northern edge of the front to $2^{\circ}$ latitude northern of the front, and between a longitudinal area of $2^{\circ}$ of the line surveyed when crossing the front.

Seabird surveys were conducted using 300 to $600 \mathrm{~m}$ strip-transects (Spear et al. 1992). Survey strip-width differed, depending on height of the observation platform (10 to $15 \mathrm{~m}$ above sea level). We counted all seabirds seen within the survey strip off 1 forequarter of the ship's bow while the ship was underway during daylight. Two to 4 persons conducted the surveys from the flying bridge, with at least 2 on watch simultaneously. Data for each bird sighting included species, number, and behavior (sitting on the water, foraging, or flying in a steady direction). We recorded flight direction to the nearest $10^{\circ}$ for birds flying in a steady direction.

Every $0.5 \mathrm{~h}$ we recorded the ship's position, speed, course, sea-surface temperature $\left({ }^{\circ} \mathrm{C}\right)$ and salinity (ppt), wind speed $\left(\mathrm{km} \mathrm{h}^{-1}\right)$ and wind direction. In 1998, chlorophyll a ( $\mathrm{mg} \mathrm{l}^{-1}$ ) was also monitored. To monitor thermal structure of the water column, ship personnel conducted expendable bathythermographs (XBTs) and CTDs 6 to 8 times each $24 \mathrm{~h}$. We define 'thermocline depth' as the point where the warm surface layer meets cooler water below, i.e., the shallowest inflection point as determined visually from XBT printouts plotting temperature as a function of depth. We measured 'thermocline slope', or the intensity of the stratification of that layer, as the temperature difference (to the nearest $0.1^{\circ} \mathrm{C}$ ) between the first obvious thermal inflection and a point $20 \mathrm{~m}$ below it. If no obvious inflection was present, then the thermocline depth was recorded as zero (i.e. at the surface). A region with strong upwelling or mixing in the water column has a shallow thermocline depth with little thermal stratification; the reverse is true where little mixing is occurring.

To avoid confusion, it should be noted that a front consists of a thermal gradient that is horizontal in nature, although the thermal boundary that it creates is vertical. On the other hand, the thermal gradient of the thermocline is vertical, although the thermal boundary is horizontal. 
Analyses. We divided the seabird community into 2 feeding guilds. The first (planktivores/small-piscivores, hereafter 'planktivores') included small Pterodroma spp. petrels (mass $<180 \mathrm{~g}$ ), storm-petrels (oceanitids), and phalaropes (Phalaropus spp.); the second (piscivores) included all other species.

To estimate densities, we corrected seabird counts for the effect of flight speed and direction of birds relative to ship speed and course (Spear et al. 1992; flight speeds from Spear \& Ainley 1997b). Without these corrections, densities from at-sea survey data are usually overestimated for birds that fly faster than the vessel and underestimated for birds that fly slower, such as storm-petrels. The correction is also required because any patterns in bird/ship direction will bias analyses. For example, if birds flew north and south at the same speed and in equal numbers, uncorrected counts from a ship transiting north would falsely indicate greater numbers flying south.

We calculated densities for each $0.5 \mathrm{hr}$ transect by dividing the corrected count by the number of $\mathrm{km}^{2}$ surveyed. Unless noted otherwise, all abundance estimates pertain to corrected counts, with variance given as 1 standard error.

In the following analyses we considered 3 'water types': the SEC, the front, and the NECC, and divided the study area into 2 longitudinal sections: east section, 100 to $120^{\circ} \mathrm{W}$; west section, 120.01 to $145^{\circ} \mathrm{W}$. We considered 2 seasons: autumn, October through December (upwelling period, see Wyrtki 1966); and spring, April through June (non-upwelling period). Following Trenberth (1997), we classified interannual variation in climate into 3 categories pertaining to El Niño Southern Oscillation (ENSO): El Niño, La Niña, and, for all other times, 'normal' (Table 1).

Our seabird survey effort for the 28 crossings in which the data qualified for analyses (see foregoing subsection) included 1194 transects of 30 min duration. For spring and autumn we surveyed 3071.3 and $4722.0 \mathrm{~km}^{2}$ of ocean area, for east and west sections of area 3252.5 and $4540.8 \mathrm{~km}^{2}$, respectively. Our survey effort for the SEC, front, and NECC covered 2654.9, 2014.3 and $3124.1 \mathrm{~km}^{2}$, and for El Niño, normal, and La Niña periods 2311.3, 3908.5 , and $1573.5 \mathrm{~km}^{2}$, respectively.

Our data for calculation of the north-south width of the front included 13 crossings during El Niño, 21 crossings during normal periods, and 11 crossings during La Niña. However, because of annual variability in front width in combination with the unequal numbers of crossings for a given year, we used only 1 measurement for each yearseason-section. Hence, we averaged the distances if more than 1 crossing was made during a given year, season, and section. Considering year (10), season (2), and section (2), 40 measurements of front width were possible. However, subtracting for seasons when cruises
Table 1. Season and year of the occurrences of El Niño, La Niña and normal conditions during this study (from Trenberth 1997; La Niña 1998 from R. Legeckis ${ }^{1}$ )

\begin{tabular}{|lll|}
\hline $\begin{array}{l}\text { Climatic } \\
\text { condition }\end{array}$ & Spring & Autumn \\
\hline El Niño & 1987,1991 & $1986,1987,1991$ \\
Normal & $1984,1986,1990$ & $1983,1985,1989,1990$ \\
La Niña & $1985,1988,1989$ & $1984,1988,1998$ \\
\hline
\end{tabular}

were not conducted in either section (spring 1983 and 1998, 4 measurements missed), absence of cruises for the east section during spring 1989 and west section during autumn 1998 (2 measurements missed), and crossings in which no front was detected (7), the sample size for measurements of front width was 27 crossings.

Employing STATA (CRC 1995), we used multiple regression analyses and Sidak multiple-comparison tests (an improved version of the Bonferroni test; SAS Institute Inc. 1985) to compare seabird densities among sections, seasons, and ENSO periods. The sample unit was one 30 min transect. We log-transformed seabird densities to satisfy assumptions of normality (Skewness/kurtosis test for normality of residuals, $\mathrm{p}>0.05)$. Because no planktivores were seen during 467 (39\%) of the 1194 transects, and no piscivores during 617 (52\%), density estimates included many values of zero. To avoid negative values of log-density, densities were multiplied by 100 and then transformed as the log (density +1 ). Experimentation with different modifications (e.g. log [density + 0.5]) showed no appreciable effect of choice of modifications on p-values. All ANOVAs were of the log-transformed density values. Normality of residuals was not achieved in all analyses, but least-squares regression (ANOVA) is considered to be very robust with respect to non-normality (Seber 1977, Kleinbaum et al. 1988). Although regression analyses yield the best linear unbiased estimator relating density to independent variables, even in the absence of normally-distributed residuals, p-values at the lower levels of significance must be regarded with caution (Seber 1977).

In the regression analyses we assigned numbers to different categories of season, east-west sections, ENSO period, and water type. These numbers were: season, (1) spring, (2) autumn; section, (1) east, (2) west; ENSO period, (1) El Niño, (2) normal, (3) La Niña; water type, (1) SEC, (2) front, (3) NECC. Preliminary analyses indicated that relationships between both planktivore and piscivore densities were linearly related across the 3 ENSO categories, so this variable was analyzed as con-

\footnotetext{
${ }^{1}$ The return of La Niña in 1998 as observed by the GOES satellite. NOAA/NESDIS/Office of Research and Application. Available at: http://140.90.191.231/oppt/loops/goes_sst/ brief_dis.html
} 
tinuous. The same was true among piscivores for water type, but not among planktivores. Therefore, we analyzed water types as continuous in analyses on abundance in piscivores, and categorical for planktivores.

\section{RESULTS}

\section{Front dynamics}

The front was absent during 7 (21\%) of the 34 crossings (Fig. 2). There was only 1 crossing in which no significant front was evident in the east section, and that occurred during El Niño; those in which the front was absent in the west section occurred during El Niño $(40 \%)$, normal $(37 \%)$ periods and La Niña $(25 \%$ of those crossings).

When present, the width of the front averaged 218 $\mathrm{km}, \mathrm{SE}=28(\mathrm{n}=27$; range, $0.01 \mathrm{~km}$ [autumn 1998] to $546 \mathrm{~km}$ [autumn 1990]). A multiple regression model, accounting for $55.4 \%$ of the variance in front width, indicated that distance differed significantly depending on ENSO period and season (Table 2). However, relative to front width, a significant interaction existed between ENSO period and season. In spring, ENSO period had no effect; in autumn, front width was greatest during El Niño and least during La Niña (difference significant between each period, Sidak tests, all $\mathrm{p}<0.0001$, Fig. 3).

Between seasons, front width observed during El Niño, normal, and La Niña periods in spring was similar to front width observed during El Niño and normal periods during autumn (Sidak tests, all $\mathrm{p}>0.8$ ). Thus, only the narrow front width observed during La Niña

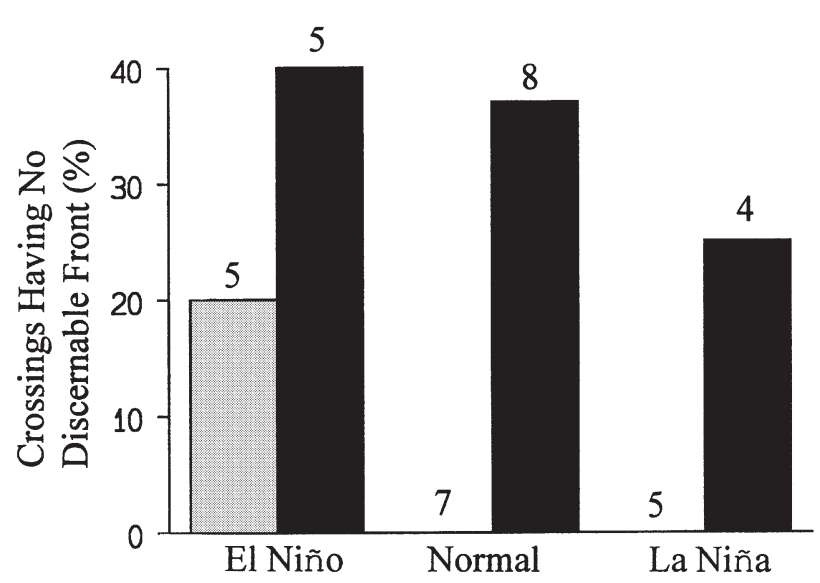

Fig. 2. Proportion of crossings between the South Equatorial Current and North Equatorial Countercurrent in which no front was discerned. Data are shown as a function of period in the El Niño Southern Oscillation and longitudinal section; east (shaded bar) and west (black bar). Numbers above bars: total number of crossings between the 2 current systems
Table 2. Multiple regression model for relationship between north-south width of the Equatorial Front and ENSO period, season (spring and autumn), and section (east and west). The rejected term, section, was re-entered into the model as a main effect when testing for interactions. Two terms separated by ' $x$ ' denote an interaction between respective terms. Regression df was 1 for each term; sample size was 27 crossings. Model $F[4,22]=6.82, \mathrm{p}<0.0001,55.4 \%$ explained

\begin{tabular}{|lccc|}
\hline Term & $\begin{array}{c}\text { Regression } \\
\text { coefficient } \pm \text { SE }\end{array}$ & $F$ & $p$ \\
\hline Main effects & & & \\
ENSO period & $-0.72 \pm 0.28$ & 6.74 & 0.016 \\
Season & $-0.95 \pm 0.43$ & 4.79 & 0.039 \\
Interactions & & & \\
ENSO $\times$ Season & $-1.45 \pm 0.50$ & 8.45 & 0.008 \\
Spring & - & 0.50 & 0.5 \\
Autumn & $-1.34 \pm 0.38$ & 12.49 & 0.003 \\
Rejected terms & & & \\
Section & $0.83 \pm 0.42$ & 3.98 & 0.058 \\
ENSO $\times$ Section & - & 0.16 & 0.7 \\
Season $\times$ Section & - & 0.00 & 1.0 \\
& & & \\
\hline
\end{tabular}

in autumn was significantly different from that recorded during other seasons and periods (Sidak tests, all $\mathrm{p}<0.05)$.

\section{Oceanographic conditions}

During the study, oceanographic characteristics of the boundary waters of the SEC and NECC were consistent with those described by Wyrtki (1966) and Fiedler et al. (1991). The following provides information for comparison with oceanographic properties of the front.

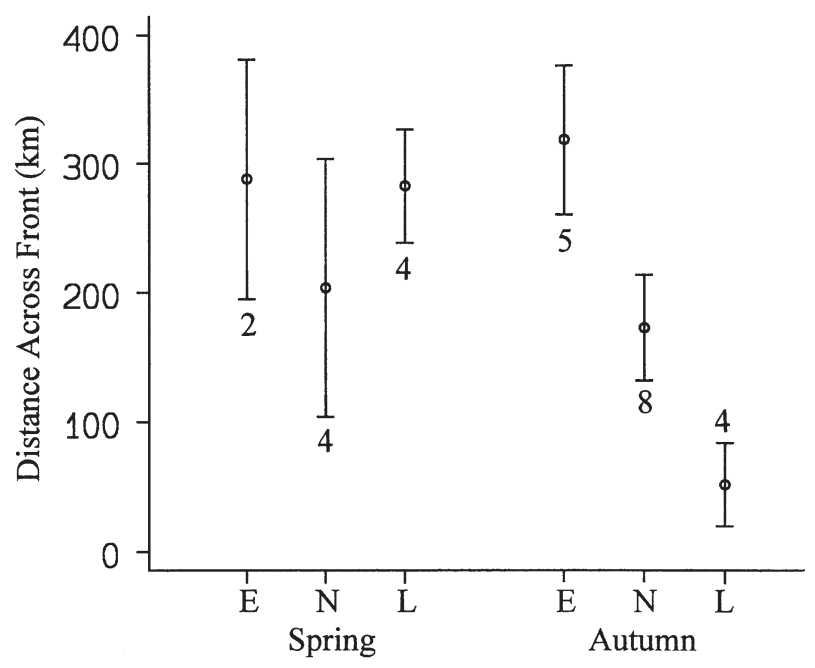

Fig. 3. Width (mean \pm SE) of the Equatorial Front as a function of season and period in the El Niño Southern Oscillation. 'E': El Niño; 'N': normal; 'L': La Niña; numbers next to SE: number of crossings in which a front was discerned 
For a given season, sea-surface temperature differed significantly among each of the 3 water types, being lowest in the northern boundary of the SEC and highest in the southern boundary of the NECC (Sidak tests, $\mathrm{p}<0.0001$; Fig. 4). For a given water type, sea-surface temperature was higher in spring than in autumn. Similarly, sea-surface salinity differed significantly among each of the 3 water types for each season, being highest in the SEC and lowest in the NECC (Sidak tests, p < 0.01, Fig. 4). Salinity was also significantly higher during spring than autumn in the SEC and front, but there was no significant difference between seasons in the NECC.

During spring, thermocline depth was significantly shallower at the front than in the boundary waters of the SEC and NECC (Sidak tests, p < 0.01, Fig. 4), but was not significantly different between the NECC and SEC. During autumn, thermocline depth differed insignificantly between the SEC and front, but was significantly deeper in the NECC than in the latter 2
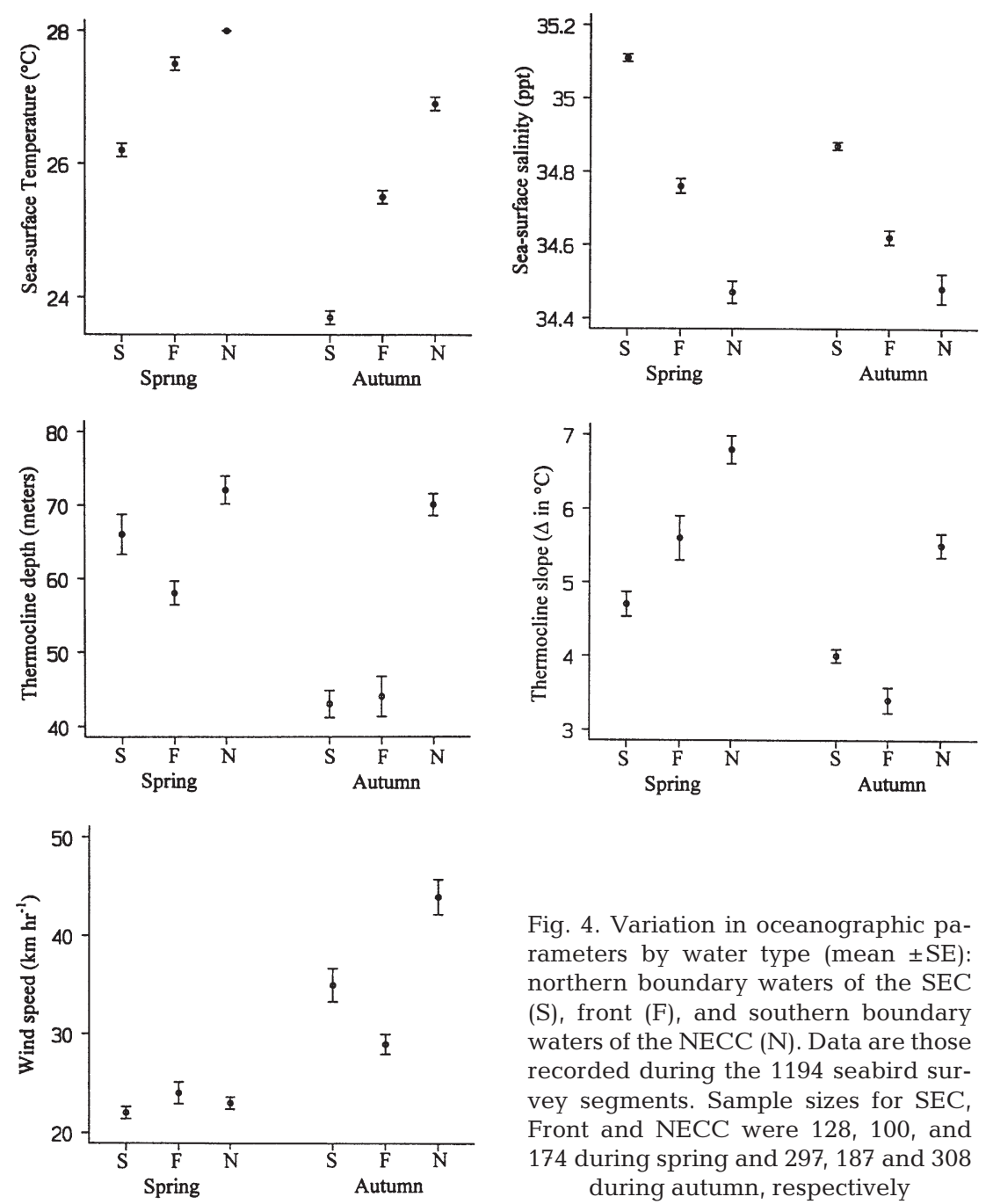

systems (Sidak tests, $\mathrm{p}<0.0001$, Fig. 4). Thermocline depth was shallower in the SEC and front during autumn than during spring, but was not significantly different between seasons in the NECC.

During spring, thermocline slope differed significantly among water types (Sidak tests, p < 0.001, Fig. 4). Mixing of the surface layer was greatest in the SEC, least in the NECC, and intermediate at the front. Thermocline slope also differed significantly among the 3 water types during autumn. In that season the difference was due to greater mixing in the front, moderate mixing in the SEC, and least mixing in the NECC. Mixing was greater during autumn than spring for each water type (Sidak tests, $\mathrm{p}<0.01$ ).

There were no significant differences in wind speed among the water types during spring (Sidak tests, all p > 0.5, Fig. 4). During autumn, however, wind speeds differed significantly among each water type. Speeds were lowest at the front, highest in the NECC, and intermediate at the SEC (Sidak tests, all $\mathrm{p}<0.001$ ). Wind speed was higher during autumn than spring for each water type (Sidak tests, all $\mathrm{p}<0.001)$.

In summary, the average sea-surface temperature and salinity at the front was midway between those of the SEC and NECC, and the thermocline was shallower at the front during spring and less stratified during autumn. Thermocline depth at the front (and also in the SEC) was shallowest during autumn.

The front was most developed during La Niña, least developed during El Niño, and stronger during autumn than spring. There was also a tendency for the front to be more developed in the eastern $\left(100\right.$ to $\left.120^{\circ} \mathrm{W}\right)$ versus western (120 to $145^{\circ} \mathrm{W}$ ) waters of the ETP (see Wyrtki 1966, for similar conclusions).

\section{Species composition}

Five species of planktivores contributed $5 \%$ or more of the total individuals recorded at the front and at the boundaries of the SEC and NECC (Fig. 5): Leach's and Galápagos stormpetrels (Oceanodroma leucorhoa and O. tethys), and white-winged, blackwinged, and Stejneger's petrels (Pterodroma leucoptera, $P$. nigripennis, and $P$. longirostris). Together, these 5 species comprised 91 to $97 \%$ of the planktivores seen at each water type. By far the most 
abundant planktivore was Leach's storm-petrel, with $70 \%$ of the individuals seen at the front and $61 \%$ in the SEC and NECC. The second most abundant planktivore, the Galápagos storm-petrel, comprised $21 \%$ of the planktivores recorded in the SEC, $14 \%$ at the front, and $9 \%$ in the NECC.

Species composition differed significantly among the 3 water types. Higher proportions of Leach's stormpetrels occurred at the front; Galápagos storm-petrels at the SEC; and white-winged, black-winged, and Stejneger's petrels at the NECC $(\mathrm{G}=72.84, \mathrm{df}=8, \mathrm{p}<$ 0.0001; Fig. 5).

The sooty tern (Sterna fuscata), wedge-tailed shearwater (Puffinus pacificus), and Juan Fernandez petrel (Pterodroma externa) were the only avian piscivores that contributed at least $5 \%$ of the individuals seen at the front and the boundaries of the SEC and NECC (Fig. 5). Together, they comprised 85 to $91 \%$ of piscivores seen in the 3 water types. Species composition
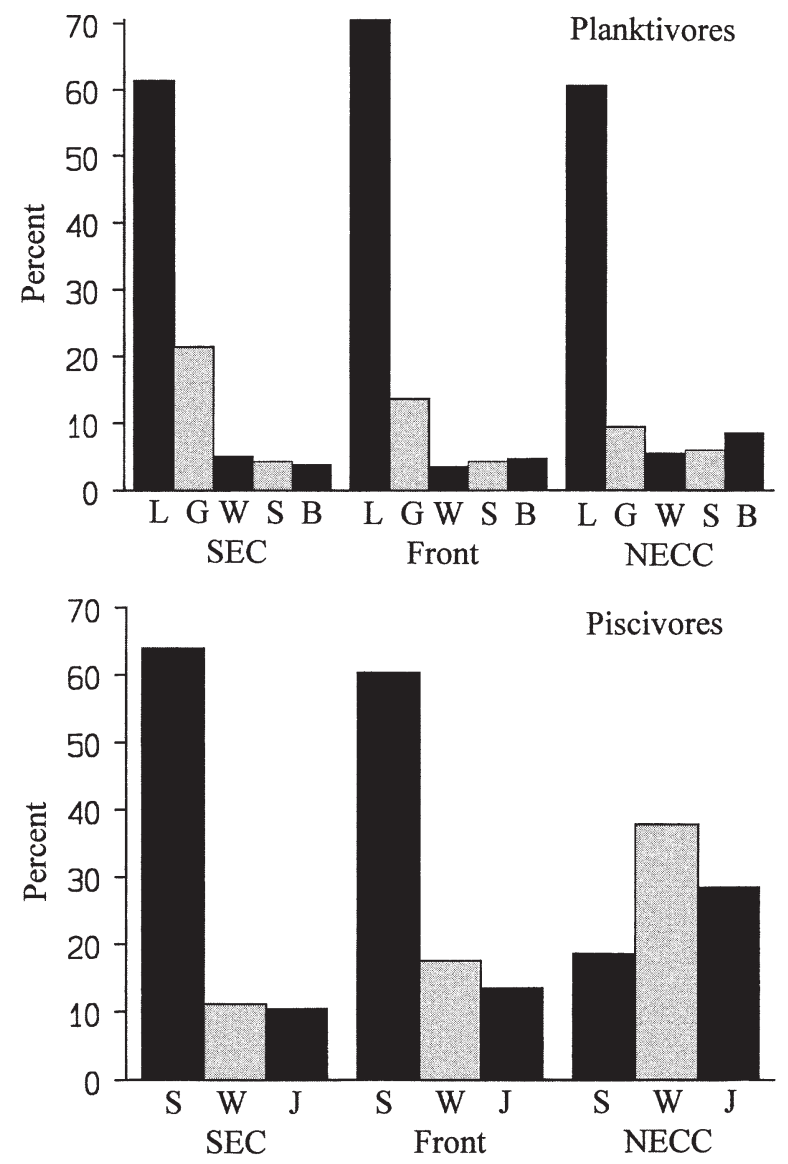

Fig. 5. Species composition as a function of water type. Percentages are the proportion of all individuals recorded for each guild. Planktivores: $\mathrm{L}=$ Leach's storm-petrel; $\mathrm{G}=$ Galápagos storm-petrel; $\mathrm{W}=$ white-winged petrel $; \mathrm{S}=$ Stejneger's petrel $; \mathrm{B}=$ black-winged petrel $;$ piscivores: $\mathrm{S}=$ sooty tern; $\mathrm{W}=$ wedge-tailed shearwater; $\mathrm{J}=$ Juan Fernandez petrel differed significantly among water types (G-test = 722.29, df $=4, \mathrm{p}<0.0001$ ). There was a high proportion of sooty terns in the SEC and front and higher proportions of wedge-tailed shearwaters and Juan Fernandez petrels in the NECC.

\section{Planktivore abundance}

The model relating abundance of planktivorous seabirds to water type, ENSO period, season and longitudinal section was highly significant, but accounted for only $8.3 \%$ of the variance (Table 3 ). Water type and ENSO period both had significant main effects on planktivore density. Higher densities occurred at the front than in the boundary waters of the SEC and NECC (Sidak tests, all $\mathrm{p}<0.01$; Fig. 6A); densities did not differ significantly between the SEC and NECC ( $p$ > 0.8). Density also declined significantly from El Niño through normal to La Niña periods (Sidak tests, all $\mathrm{p}<0.05$, Fig. 6B).

Table 3. Multiple regression model for relationship between log-planktivore density and ENSO period (El Niño, normal, and La Niña), water type (SEC, Front, NECC), season (spring and autumn), and longitude section (east and west). Water type was analyzed as categorical. The rejected terms, season and section, were re-entered into the model as main effects when testing for interactions. Sample size was 1194 survey transects, each of 30 min. Model $F[12,1181]=8.16, p<$ 0.0001 , accounted for $8.3 \%$ of the variance

\begin{tabular}{|lcrlr|}
\hline Term & $\begin{array}{c}\text { Regression } \\
\text { coefficient } \pm \text { SE }\end{array}$ & $F$ & $p$ & df \\
\hline Main effects & & & & \\
Water type & - & 4.93 & 0.007 & 2 \\
ENSO period & $-0.25 \pm 0.073$ & 11.35 & 0.008 & 1 \\
Interactions & & & & \\
Water type $\times$ ENSO & - & 20.60 & $<0.0001$ & 2 \\
SEC & $-0.75 \pm 0.12$ & 39.19 & $<0.0001$ & 1 \\
Front & $0.47 \pm 0.15$ & 9.59 & 0.002 & 1 \\
NECC & - & 2.69 & 0.1 & 1 \\
Water type $\times$ Season & - & 4.83 & 0.008 & 2 \\
SEC & - & 0.00 & 1.0 & 1 \\
Front & $0.80 \pm 0.22$ & 13.11 & 0.0003 & 1 \\
NECC & - & 0.00 & 1.0 & 1 \\
Water type $\times$ Section & - & 7.75 & 0.0005 & 2 \\
SEC & $-0.35 \pm 0.19$ & 3.53 & 0.061 & 1 \\
Front & - & 0.63 & 0.4 & 1 \\
NECC & $0.39 \pm 0.16$ & 5.67 & 0.018 & 1 \\
ENSO $\times$ Section & $0.41 \pm 0.14$ & 7.99 & 0.005 & 1 \\
East & $-0.52 \pm 0.10$ & 25.51 & $<0.0001$ & 1 \\
West & - & 0.00 & 1.0 & 1 \\
Rejected terms & & & & \\
Longitude section & - & 0.33 & 0.5 & 1 \\
Season & $0.21 \pm 0.12$ & 3.35 & 0.067 & 1 \\
Section $\times$ Season & - & 2.20 & 0.14 & 1 \\
ENSO $\times$ Season & - & 2.55 & 0.11 & 1 \\
& & & & \\
\hline
\end{tabular}



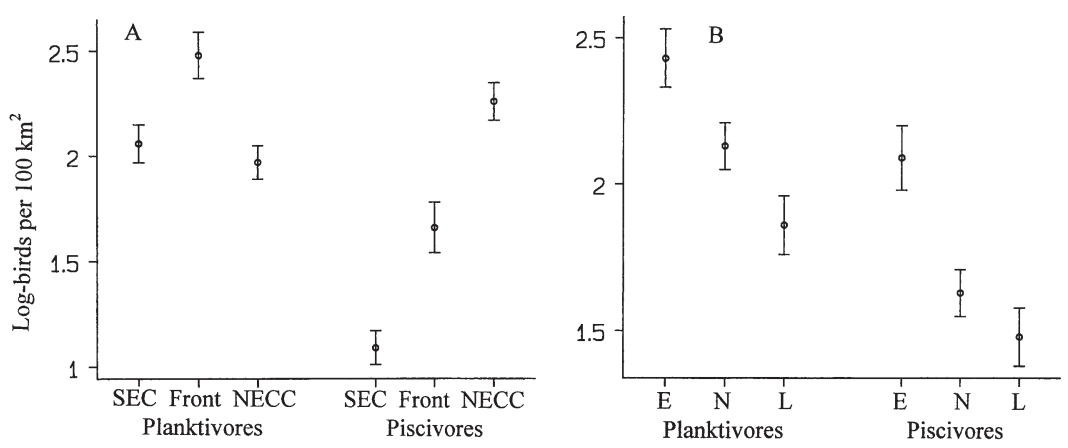

Fig. 6. Relationship (means $\pm \mathrm{SE}$ ) of planktivore and piscivore densities (log-birds per $100 \mathrm{~km}^{2}$ ) with (A) water type, and (B) ENSO period. Sample sizes for water type were 425, 287, and 482, and for ENSO period were 295, 529, and 370

Water type and ENSO period, as well as season and section (both insignificant as main effects) each were involved in 1 or more interactions with each other (Table 3). The effect of water type on planktivore density interacted with each of the other 3 variables; the effect of ENSO period also interacted with longitudinal section.

The interaction between water type and ENSO period was due to: (1) a significant negative relation between planktivore density and ENSO period in the SEC, indicating that densities in the SEC were highest during El Niño and lowest during La Niña (Table 3, Fig. 7A); (2) a significant increase in density with ENSO period at the front, where densities were lowest during El Niño and highest during La Niña; (3) lack of a significant relationship between density and ENSO in the NECC.

The interaction between ENSO period and section reflected a significant decrease in planktivore density with ENSO period in the east section compared to no relationship in the west section (Table 3, Fig. 7B). Thus, densities were highest during El Niño and lowest during La Niña in the eastern section.

The interaction between water type and season reflected the significantly higher densities found during autumn than during spring in front waters, compared to no seasonal differences in both the SEC and NECC (Fig. 7C).

Finally, the interaction between water type and longitude section was due to significantly higher densities of planktivores in the east vs. west sections in the SEC compared to higher densities in west versus east in the NECC and lack of a significant difference between sections at the front (Fig. 7D).

In summary, during La Niña, planktivore abundance was low in the SEC and high at the front, where densities were higher during autumn compared to spring. In the east, densities were highest during El Niño, intermediate during normal periods, and lowest during La Niña, but differed little among ENSO periods in the west. Densities were higher in the east than in the west sections of the SEC, the reverse was true for the NECC, but densities differed little between sections at the front.

\section{Piscivore abundance}

The model relating abundance of piscivore seabirds with water type, ENSO period, season and longitudinal section accounted for $20.7 \%$ of the variance (Table 4). Each of the 4 covariates had significant main effects on piscivore abundance (Table 4). The relationship with water type reflected a significant increase in

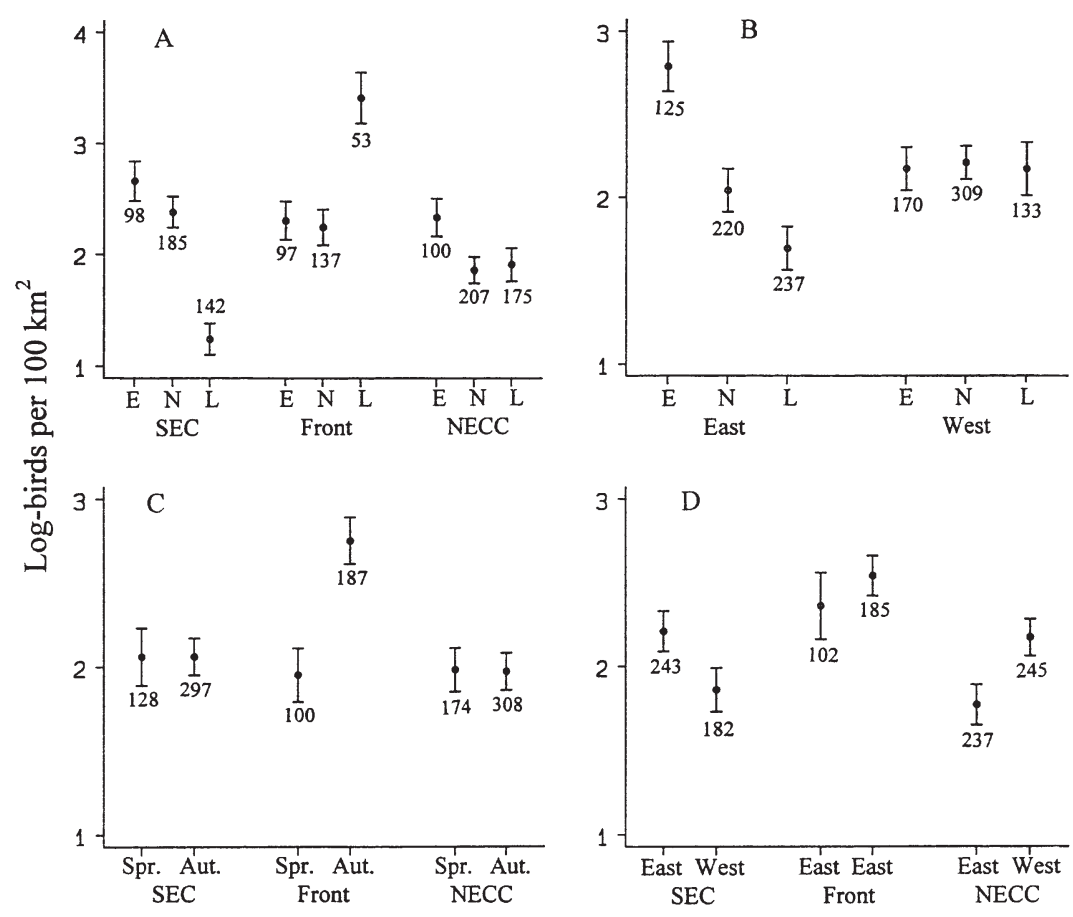

Fig. 7. Planktivore density (log-birds per $100 \mathrm{~km}^{2}$ ) as a function of season, water type, and section. Interactions between (A) ENSO period and water type, (B) ENSO period and longitude section, (C) water type and season, and (D) water type and longitude section. E: El Niño; N: normal; L: La Niña; West: 100 to $120^{\circ} \mathrm{W}$; East: $120^{\circ} 01^{\prime}$ to $140^{\circ} \mathrm{W}$; Spr., Aut.: spring and autumn respectively 
density from the boundary waters of the SEC through the front to the boundary waters of the NECC (Sidak tests, all $\mathrm{p}<0.0001$, Fig. 6A). Differences between ENSO periods were due to higher densities during El Niño compared to normal and La Niña periods (Sidak tests, both $\mathrm{p}<0.01$, Fig. 6B); densities did not differ significantly between normal and La Niña periods ( $p>0.6)$.

Each of the 4 covariates was involved in 1 or more interactions with another (Table 4). The interaction between ENSO period and section was due to a significant increase in piscivore density with ENSO period in the east compared to a significant, opposite relationship in the west section (Table 4, Fig. 8A). Thus, densities were highest during La Niña and lowest during El Niño in the east, but highest during El Niño and lowest during La Niña in the west.

The interaction between water type and season reflected the highly significant difference in densities between spring and autumn in the SEC and front waters (densities were higher during spring) vs. a less significant difference in the NECC (Fig. 8B).

An interaction between season and section reflected an insignificant difference in piscivore densities between seasons in the east, compared to considerably higher densities in spring compared to autumn in the west (Fig. 8C).

\section{Oceanographic variables related to seabird densities}

Of the 9 significant correlations between densities of planktivorous seabirds and oceanographic variables in the study area, 7 occurred during autumn (Table 5). During El Niño there were no correlations during spring. In autumn, however, planktivore densities increased with decreasing water temperature and increasing thermocline depth. During normal years, densities increased with decreasing thermocline slope during both spring and autumn, and in autumn, they also increased with decreasing sea-surface temperature and wind speed. During La Niña, planktivore den-
Table 4. Multiple regression model for relationship between log-piscivore density and ENSO period (El Niño, normal, and La Niña), water type (SEC, Front, NECC), season (spring and autumn), and longitude section (east and west). All variables analyzed as continuous. Sample size was 1194 survey transects each of $30 \mathrm{~min}$. All numerator df $=1$. Model $F[7,1186]=$

$44.26, \mathrm{p}<0.0001$, accounted for $20.7 \%$ of the variance

\begin{tabular}{|lccc|}
\hline Term & $\begin{array}{c}\text { Regression } \\
\text { coefficient } \pm \text { SE }\end{array}$ & $F$ & $p$ \\
\hline Main effects & & & \\
Water type & $0.55 \pm 0.061$ & 81.09 & $<0.0001$ \\
ENSO period & $-0.25 \pm 0.073$ & 12.17 & 0.0005 \\
Season & $-0.66 \pm 0.11$ & 33.08 & $<0.0001$ \\
Longitude section & $0.55 \pm 0.11$ & 24.98 & $<0.0001$ \\
Interactions & & & \\
Water type $\times$ Season & $-0.78 \pm 0.23$ & 8.06 & 0.005 \\
SEC & $-1.07 \pm 0.18$ & 36.89 & $<0.0001$ \\
Front & $-1.04 \pm 0.24$ & 19.49 & $<0.0001$ \\
NECC & $-0.41 \pm 0.19$ & 4.70 & 0.031 \\
ENSO $\times$ Section & $0.35 \pm 0.13$ & 89.69 & $<0.0001$ \\
East & $0.43 \pm 0.095$ & 21.12 & $<0.0001$ \\
West & $-0.95 \pm 0.11$ & 71.57 & $<0.0001$ \\
Season $\times$ Section & $-1.32 \pm 0.14$ & 12.13 & 0.0005 \\
East & $-0.23 \pm 0.17$ & 1.75 & 0.2 \\
West & $-1.02 \pm 0.16$ & 39.35 & $<0.0001$ \\
Rejected terms & & & \\
ENSO $\times$ Section & - & 0.00 & 1.0 \\
ENSO $\times$ Season & - & 1.15 & 0.3 \\
Water type $\times$ Section & - & 0.63 & 0.4 \\
& & & \\
\hline
\end{tabular}

sities increased with decrease in thermocline depth in both spring and autumn, and also with decreasing wind speed during autumn. Thus, the general trends during non El Niño years were for higher densities of planktivores in more mixed waters with shallow thermoclines and where wind speeds were lower.

Of the 16 significant oceanographic relationships among piscivores, 7 and 9 occurred during spring and autumn respectively (Table 5). Of these relationships, 5 occurred in El Niño, 6 during normal periods, and 5
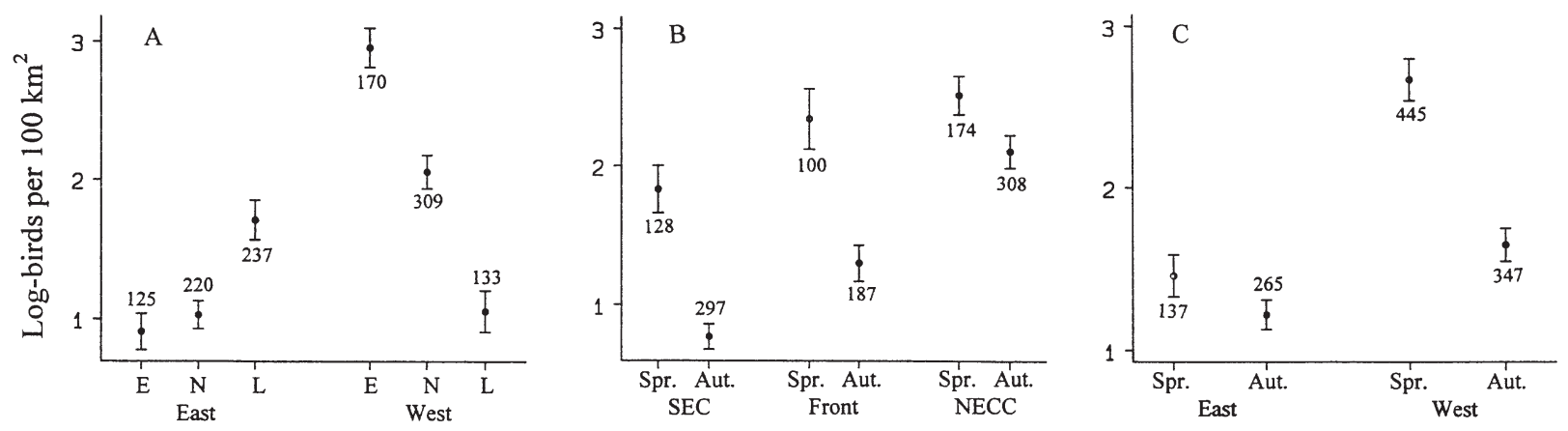

Fig. 8. Piscivore density (log-birds per $100 \mathrm{~km}^{2}$ ) as a function of season, water type, and section. Interactions between (A) ENSO period and longitude section, (B) water type and season, and (C) season and longitude section. Further details as in Fig. 7 
during La Niña. All of the 10 correlations of density with sea-surface temperature and thermocline depth were positive. The 2 correlations with thermocline slope were also positive, and the 2 correlations with sea-surface salinity were both negative. Piscivore densities also increased with decreasing wind speed during El Niño, and with increasing wind speed during normal periods. Thus, there was a general trend for piscivore densities to be higher where sea-surface temperature was high, salinity low, and the thermocline was deep and stratified.

\section{Characteristics of the unusual Equatorial Front during La Niña 1998}

The front was particularly sharp when encountered on 11 October 1998, at $3^{\circ} 39^{\prime} \mathrm{N}, 117^{\circ} 39^{\prime} \mathrm{W}$ (Fig. 1; note that the front in the image is not at this location due to lack of real-time imagery in the satellite composite). The front was visible from a distance of several kilometers due to a change in water color from 'blue' on the NECC side to 'green' on the SEC side, and the presence of appreciable surface turbulence immediately at the front. The front itself appeared to be no more than $10 \mathrm{~m}$ wide based on $1.5 \mathrm{~m}$ ocean waves of

Table 5. Summary results of regression analyses on relationship of log-density (birds $100 \mathrm{~km}^{-2}$ ) of planktivorous and piscivorous seabirds with oceanographic variables in the study area during the 3 ENSO periods. Each independent variable was analyzed as continuous. Signs in parentheses denote signs of the regression coefficient, indicating positive (+) or negative (-) slope; followed by p-values; ns: not insignificant. Sample sizes for each ENSO period/season are given in Fig. 6 legend

\begin{tabular}{|c|c|c|c|c|c|}
\hline & $\begin{array}{r}\text { Sea-su } \\
\text { temperature }\end{array}$ & $\begin{array}{l}\text { rface } \\
\text { salinity }\end{array}$ & $\begin{array}{l}\text { Therm } \\
\text { depth }\end{array}$ & $\begin{array}{l}\text { cline } \\
\text { slope }\end{array}$ & $\begin{array}{l}\text { Wind } \\
\text { speed }\end{array}$ \\
\hline \multicolumn{6}{|c|}{ Planktivores } \\
\hline \multicolumn{6}{|c|}{ El Niño } \\
\hline Spring & $\mathrm{ns}$ & ns & $\mathrm{ns}$ & ns & ns \\
\hline Autumn & (-) 0.03 & ns & (+) 0.01 & $\mathrm{~ns}$ & ns \\
\hline \multicolumn{6}{|l|}{ Normal } \\
\hline Spring & ns & ns & ns & (-) 0.05 & ns \\
\hline Autumn & (-) 0.04 & ns & ns & (-) 0.05 & $(-) 0.03$ \\
\hline \multicolumn{6}{|l|}{ La Niña } \\
\hline Spring & ns & ns & $(-) 0.01$ & ns & ns \\
\hline Autumn & ns & ns & (-) 0.03 & ns & (-) 0.0001 \\
\hline \multicolumn{6}{|l|}{ Piscivores } \\
\hline \multicolumn{6}{|l|}{ El Niño } \\
\hline Spring & (+) 0.02 & ns & ns & (+) 0.02 & (-) 0.001 \\
\hline Autumn & (+) 0.0001 & ns & (+) 0.0001 & ns & $\mathrm{ns}$ \\
\hline \multicolumn{6}{|l|}{ Normal } \\
\hline Spring & (+) 0.0001 & $(-) 0.01$ & (+) 0.01 & ns & $\mathrm{ns}$ \\
\hline Autumn & (+) 0.0001 & ns & (+) 0.0001 & ns & (+) 0.01 \\
\hline \multicolumn{6}{|l|}{ La Niña } \\
\hline Spring & $\mathrm{ns}$ & ns & (+) 0.0001 & ns & ns \\
\hline Autumn & (+) 0.0001 & (-) 0.0001 & (+) 0.0001 & (+) 0.05 & $\mathrm{~ns}$ \\
\hline
\end{tabular}

short duration (i.e., very choppy) over the $10 \mathrm{~m}$ wide region compared to 0.7 and $0.3 \mathrm{~m}$ waves of longer duration, immediately on the NECC and SEC sides, respectively.

Moving across the wave chop from the NECC to $\mathrm{SEC}$, there was an immediate and dramatic change in oceanographic and meteorological conditions: a $2.1^{\circ} \mathrm{C}$ decrease in sea-surface temperature, a $0.2 \mathrm{ppt}$ increase in salinity, a $5.09 \mathrm{mg} \mathrm{l}^{-1}$ increase in chlorophyll $a$, and an $11 \mathrm{~km} \mathrm{~h}^{-1}$ decrease in wind speed (Table 6). There was also a $54 \mathrm{~m}$ decrease in thermocline depth and a $2.1^{\circ} \mathrm{C}$ decrease in thermocline slope, indicating considerable decrease in depth and stratification of the thermal layer on the NECC versus SEC sides of the front.

We compared densities among species assemblages encountered on the front with those at the SEC and NECC, based on surveys during $3 \mathrm{~d}$ (Table 7). The surveys on the front were possible after the ship's course was diverted to transit parallel to it, such that the turbulent water area was always within the $300 \mathrm{~m}$-wide survey strip (see 'Study area and methods').

Planktivore densities were significantly higher on the front than on the SEC or NECC sides (Sidak tests, both $\mathrm{p}<0.0001$, Table 7) but were not significantly different between the SEC and NECC sides of the front $(p=0.8)$. In contrast, densities of piscivores did not differ significantly among the 3 water types (all $\mathrm{p}>0.2$ ). In general, these results are similar to those observed when the front was less developed although, for planktivores, the observed abundance was elevated considerably during the 1998 crossing (see preceeding subsection).

The sightings of a red-billed tropicbird (Phaethon aethereus) in SEC waters immediately to the south of the front $\left(3^{\circ} 15^{\prime} \mathrm{N}, 116^{\circ} 55^{\prime} \mathrm{W}\right)$ and red and red-necked phalaropes (Phalaropus fulicarius and P. lobatus) on the front, represent westward range extensions in equatorial Pacific waters $\left(10^{\circ} \mathrm{N}\right.$ to $10^{\circ} \mathrm{S}$ ) for each species (Table 8). Prior to these sightings, the westernmost records in these waters were at $97^{\circ} 37^{\prime} \mathrm{W}\left(2^{\circ} 11^{\prime} \mathrm{N}\right), 110^{\circ} 08^{\prime} \mathrm{W}\left(2^{\circ} 23^{\prime} \mathrm{N}\right)$, and $81^{\circ} 17^{\prime} \mathrm{W}\left(4^{\circ} 54^{\prime} \mathrm{S}\right)$, respectively (Spear, Ballance, \& Ainley unpubl. data). Thus, the 1998 sightings represent range extensions of 2150, 850, and $4000 \mathrm{~km}$, respectively. Indeed, before 1998, we had not seen the Rednecked Phalarope more than $165 \mathrm{~km}$ from shore. 
Table 6. Changes in oceanographic and climatological variables when passing across front from north to south on 11 October 1998 (La Niña), at $3^{\circ} 34^{\prime} \mathrm{N}$, $117^{\circ} 37^{\prime} \mathrm{W}$, eastern tropical Pacific. Sea-surface temperature (SST), and salinity (SSS), thermocline depth (TDPT) and slope (TSLP), wind speed (WSP) and chlorophyll a (chl a). Thermocline values from XBT casts 175 (SEC side; $3^{\circ} 34.5^{\prime} \mathrm{N}, 117^{\circ} 37.1^{\prime} \mathrm{W}$ ) and 173 (NECC side; $3^{\circ} 46.7^{\prime} \mathrm{N}$, $\left.117^{\circ} 49.8^{\prime} \mathrm{W}\right)$. Thermocline slope is the change in water temperature between the beginning of the thermocline and a point $20 \mathrm{~m}$ below it

\begin{tabular}{|lcccccc|}
\hline & $\begin{array}{c}\text { SST } \\
\left({ }^{\circ} \mathrm{C}\right)\end{array}$ & $\begin{array}{c}\text { SSS } \\
(\mathrm{ppt})\end{array}$ & $\begin{array}{c}\text { TDPT } \\
(\mathrm{m})\end{array}$ & $\begin{array}{c}\text { TSLP } \\
\left({ }^{\circ} \mathrm{C}\right)\end{array}$ & $\begin{array}{c}\text { WSP } \\
\left(\mathrm{km} \mathrm{h}^{-1}\right)\end{array}$ & $\begin{array}{c}\mathrm{Chl} a \\
\left(\mathrm{mg} \mathrm{l}^{-1}\right)\end{array}$ \\
\hline $\begin{array}{l}\text { NECC side } \\
\text { of front }\end{array}$ & 25.8 & 34.00 & 65 & 3.6 & 33 & 3.84 \\
$\begin{array}{l}\text { SEC side } \\
\text { of front }\end{array}$ & 23.7 & 34.20 & 11 & 1.5 & 22 & 8.93 \\
\hline
\end{tabular}

phases of ENSO. Planktivore densities at the front were also higher during autumn than during spring, consistent with the stronger development of the front during autumn.

Schneider et al. (1987), studying seabirds in the Bering Sea, also found elevated densities associated with those fronts having the 'steepest flow gradients'. In our study, correlations of planktivore densities with shallow, less-stratified thermoclines (i.e., weak themoclines resulting from strong flow gradients) were consistent with this finding. This was particularly evident at the very strong front encountered during La Niña 1998, when planktivore densities were 122 and 61 times greater than in SEC and NECC

\section{DISCUSSION}

To our knowledge, this is the first study of seabird association with thermal boundaries in tropical oceans, in this case within the $5000 \mathrm{~km}$ stretch of waters lying between 100 and $145^{\circ} \mathrm{W}$, although the Equatorial Front occurs farther to the east and west.

\section{Planktivores}

Planktivores responded significantly to the front. Densities of planktivores, which consisted mostly of Leach's and Galápagos storm-petrels, were significantly higher at the front than in the SEC and NECC waters bordering it. Planktivores had significantly higher abundance at the front during La Niña, when it was most developed, compared to El Niño and normal

Table 7. Summary statistics on number of species, adjusted number of individuals, and survey effort on the Front, and on the SEC and NECC sides of the Front in October 1998. Comparisons do not include the migrant species Murphy's petrel (Table 8). Raw numbers of individuals are also given by species in Table 8

\begin{tabular}{|lccc|}
\hline Parameter & SEC & Front & NECC \\
\hline No. of km ${ }^{2}$ surveyed & 64.3 & 4.4 & 96.3 \\
No. of species & 7 & 6 & 4 \\
Adjusted no. of birds & 11.7 & 36.0 & 36.6 \\
Density & $0.18 \pm 0.04$ & $8.18 \pm 3.40$ & $0.38 \pm 0.13$ \\
Planktivores & & & \\
$\quad$ Adjusted no. & 4.0 & 32.0 & 11.3 \\
$\quad$ Density & $0.06 \pm 0.04$ & $7.27 \pm 1.58$ & $0.12 \pm 0.03$ \\
Piscivores & & & \\
$\quad$ Adjusted no. & 7.7 & 4.0 & 25.3 \\
Density & $0.12 \pm 0.05$ & $0.90 \pm 0.67$ & $0.26 \pm 0.05$ \\
\hline
\end{tabular}
waters, respectively, on either side of the front. Indeed, the decline in the abundance of planktivores in the NECC and in particular the SEC during La Niña suggests that the increase in abundance at the front during La Niña reflected displacement of birds from the SEC and NECC systems.

Table 8. Species and unadjusted number of seabirds recorded at, and on either side of the front in October 1998. Surveys were conducted on $3 \mathrm{~d}$ from 10 to 12 October 1998; ${ }^{*}$ species for which sighting represented extralimital occurrence. (See Table 7 for survey effort at each location)

\begin{tabular}{|c|c|c|c|}
\hline Species & $\begin{array}{l}\text { NECC side } \\
\text { of front }\end{array}$ & Front & $\begin{array}{l}\text { SEC side } \\
\text { of front }\end{array}$ \\
\hline $\begin{array}{l}\text { Juan Fernandez petrel, } \\
\text { Pterodoma externa }\end{array}$ & 32 & 1 & 7 \\
\hline $\begin{array}{l}\text { Murphy's petrel, } \\
\text { P. ultima }\end{array}$ & 1 & 0 & 0 \\
\hline $\begin{array}{l}\text { White-winged petrel, } \\
\text { P. leucoptera }\end{array}$ & 0 & 0 & 1 \\
\hline $\begin{array}{l}\text { Tahiti petrel, } \\
\text { P. rostrata }\end{array}$ & 0 & 0 & 1 \\
\hline $\begin{array}{l}\text { Harcourt's storm-petrel, } \\
\text { Oceanodroma castro }\end{array}$ & 0 & 0 & 1 \\
\hline $\begin{array}{l}\text { Leach's storm-petrel, } \\
\text { O. leucorhoa }\end{array}$ & 10 & 21 & 1 \\
\hline $\begin{array}{l}\text { Galápagos storm-petrel, } \\
\text { O. tethys }\end{array}$ & 1 & 8 & 1 \\
\hline $\begin{array}{l}\text { Great frigatebird, } \\
\text { Fregeta minor }\end{array}$ & 2 & 0 & 0 \\
\hline $\begin{array}{l}\text { Red-billed tropicbird*, } \\
\text { Phaethon aetherus }\end{array}$ & 0 & 0 & 1 \\
\hline $\begin{array}{l}\text { Red Phalarope* }^{*} \\
\text { Phalaropus fulicarius }\end{array}$ & 0 & 2 & 0 \\
\hline $\begin{array}{l}\text { Red-necked phalarope* } \\
\quad \text { P. lobatus }\end{array}$ & 0 & 1 & 0 \\
\hline $\begin{array}{l}\text { Sooty tern, } \\
\text { Sterna fuscata }\end{array}$ & 0 & 3 & 0 \\
\hline
\end{tabular}


However, the apparent displacement of planktivores from surrounding waters to the front during La Niña was a local phenomenon. The front itself occupies only a small area of the ETP compared with the SEC and NECC, and thus the significant decline in planktivore densities in the latter 2 water types indicated an overall decline. Hence, the primary response of these birds appears to have been avoidance (or at least preference for other regions of the Pacific; see next paragraph) of the ETP during La Niña conditions.

In summary, planktivores preferred the cooler, wellmixed waters of the front, indicating that abundance and/or availability of their prey was greatest there. Yet, the planktivores were more abundant in the study area during El Niño than during La Niña. We suspect that these paradoxical results reflected the large-scale effects of ENSO. Besides El Niño-related ocean warming and decline in primary productivity in the ETP (and probably the prey of planktivores; Barber \& Chavez 1986, 1991), it also impacts ecosystems in other, possibly preferred, parts of the species' pelagic ranges e.g. the waters of the North Pacific (Gould \& Piatt 1993) or in the vicinity of the Galápagos Islands (Crossin 1974, Pitman 1986, Spear, Ballance \& Ainley unpubl. data). As a result, many planktivores apparently disperse further than normal towards the south or west in search of favorable foraging areas, as noted for other seabird species during El Niño (e.g. Ribic et al. 1992, Spear et al. 1995). Increased densities during El Niño in the ETP could also have been related to individuals skipping a year of breeding, or to breeding failures, which could result in changes in the normal dispersal patterns of adults.

On the other hand, during La Niña, the front was probably one of several frontal systems that were strengthened because of increased horizontal transport in the Central Gyre (Ando \& McPhaden 1991, Legeckis [see Footnote 1]). Thus, although planktivore densities increased dramatically at the front, other well-developed fronts were probably available. Candidates include the Subarctic and Subtropical fronts on the north and south boundaries of the Transition zone, and the NECC (north boundary) Divergence and Galápagos Island Rifts (see Fiedler et al. 1991, Gould \& Piatt 1993). Had these been closer to the breeding grounds of Leach's and Galápagos storm-petrels, on the North Pacific Rim and Galápagos Islands respectively, than the part of the front lying between 100 and $145^{\circ} \mathrm{W}$, many of these birds could probably have found good foraging locations during their post-breeding dispersal before reaching the study area.

The strengthening of the front during La Niña also acted to extend the ranges of some species typically found in the Peru Current during the nonbreeding period. This was indicated by the recordings of Red- necked and Red phalaropes, and a Red-billed Tropicbird during autumn 1998 at the strong front found at $117^{\circ} \mathrm{W}, 800$ to $4000 \mathrm{~km}$ west of the previous westernmost recordings known for these species in the equatorial Pacific. Phalaropes are well known for their concentrations at fronts associated with the California (Briggs et al. 1984), Peru (Brown 1980) and Canary boundary (Brown 1979, Cadee 1981) currents. In this regard, our observations in the pelagic ETP during La Niña 1998 were probably related to the presence not only of a exceptionally strong front, but also to the propagation of nutrient-rich, boundary current-like waters into the ETP as the result of the increased velocity of the Peru Current merging into the SEC (Fig. 1).

\section{Piscivores}

Like planktivores, piscivores were also most abundant in the study area during El Niño, but, in contrast to planktivores, there was no evidence for an association with the front. Correlations between piscivore densities and oceanographic variables indicated a preference for waters that were warmer and with a deeper, more stratified, thermal structure. Consistent with this finding, not only were piscivore densities higher in the NECC (for similar findings see Gould 1974, King 1974, Pitman 1986, Spear et al. 1995), but they were also higher during spring than during autumn, and higher in the western versus eastern sections of the study area, when and where the front was weakest. In this regard, the avoidance by tropical piscivores of frontal regions in the ETP is in marked contrast to the patterns observed in studies of piscivorous seabirds foraging in subpolar or polar waters (see 'Introduction').

The affinity of the primary piscivore species in this study (sooty tern, wedge-tailed shearwater, and Juan Fernandez petrel) for the NECC is probably related to the distribution of surface-feeding tuna (yellowfin tuna Thunnus albacates and skipjack Katsuwonus pelamis), on which the birds depend to drive their prey to the surface (Au \& Pitman 1986, Ballance et al. 1997). Murphy \& Shomura (1972), studying tunas in the ETP, found that the NECC held the highest densities of schooling, surface-feeding tunas, but that tuna found in the SEC fed deeply and in loose groups. These authors suggested that the deep-swimming tunas fed in dispersed schools because their prey are not aggregated, whereas surface-feeding tuna fed in closely-packed schools as an adaptation for exploiting schooling prey.

The above would explain the preference of piscivorous seabirds for the NECC. However, Murphy \& Shomura (1972) also suggested that the higher abundance of schooling tunas in the NECC was due to the 
presence of a larger number of surface fronts in that current system compared to the SEC. This explanation is inconsistent with our findings, because the tunadependent piscivores were less abundant at the front than in the NECC boundary waters.

In view of the above, we wonder if the deeper more stratified thermocline characteristic of the NECC may be important as a mechanism that creates a barrier and/or gathering area for some schooling prey of tunas. Like horizontal structuring (e.g. the front, with cooler waters immediately to the south and warmer waters to the north), strong structuring in the vertical dimension (e.g. a strong thermocline, with warm surface waters lying over a cold deeper layer) also has important consequences for planktonic organisms that concentrate at sharp gradients (reviewed in Hunt 1990, see also Turner \& Dagg 1983). In turn, the distributions of their predators are affected as well. For example, Hunt et al. (1990) found that the least auklet (Aethia pusilla), a subsurface feeder in the northern Bering Sea, foraged exclusively in vertically stratified water on zooplankton that concentrate at the thermocline. Similar findings also were made by Gould \& Piatt (1993) studying seabirds in the central North Pacific. In yet another study, Reilly \& Fiedler (1994) found that spinner and spotted dolphins (Stenella longirostris and $S$. attenuata, respectively), species that regularly associate with surface-schooling yellowfin tuna, are also found in waters with deeper and stronger thermoclines.

In this regard, the majority of schooling prey of tunas are those that typically perform vertical migrations to the ocean surface at night (Olson \& Boggs 1986). A deeper thermocline such as that of the NECC (mean = $72 \mathrm{~m}$ in this study) could be attractive to these animals for hiding during the day, because of the lack of light at those depths and because of the enriched $\mathrm{O}_{2}$ content of the cold water lying immediately below a warmer, well-stratified upper thermal layer. On the other hand, diel moving prey that prefer the warmer surface waters should concentrate just above the thermocline. Hence, by searching on a horizontal plane near the subsurface boundary created by a deep, wellstratified thermal structure such as that of the NECC, schooling tuna may reliably be able to find concentrations of prey that they pursue to the ocean surface and capture more readily than an equally, or more, abundant prey that is dispersed throughout a less-stratified water column. Indeed, studies of the movements and depth distribution of surface-feeding tunas has shown that they spend the majority of their time in or immediately below the thermocline (reviewed in Brill et al. 1999). This would explain the lower avian piscivore abundance at the front (and SEC) compared to the NECC, as the front had a less well developed thermocline more similar in structure to that of the SEC. In fact, the thermocline was even shallower (spring) and less stratified (autumn) in the front.

\section{Summary}

The strong association of planktivorous seabirds with a vertical thermal boundary (the front) was consistent with the associations noted between seabirds and these structures in subpolar and polar waters. Indeed, in both polar (cf Schneider et al. 1987, Hunt 1990) and tropical systems, the stronger the front, the stronger the response of the planktivores. Yet, the spatial scale of frontal systems that have been studied in polar latitudes is several orders of magnitude smaller than that of our study, and the predictability of frontal systems in higher latitudes is also much greater in both time and space than in our study (see references in 'Introduction'). As a result, tropical planktivores, even though they use oceanographic features to locate prey, must rely on proficient flight capabilities to a much higher degree than higher-latitude frontal feeders, as already suggested (Hunt 1988, Spear \& Ainley 1997a, Ballance \& Pitman 1999).

In contrast to the planktivores, there was an absence of any association between piscivorous seabirds and the front. The evidence indicates that tropical avian piscivores rely primarily on surface-feeding tunas, which apparently are associated with the horizontal thermal boundary provided by the thermocline. The latter is much deeper and stronger in tropical versus polar waters, particularly in the North Equatorial Countercurrent (cf Wyrtki 1966) where tropical piscivores are most abundant.

Besides the sharp structuring of the thermocline, another difference in tropical versus polar systems that is probably related to differences in foraging behavior of piscivorous seabirds is differences in water clarity (Ainley 1977). In the more productive polar system the water is generally more turbid, facilitating greater use of the upper layer (especially during daylight) by prey that frequently aggregate in high densities near the surface in association with sharp vertical structuring (fronts). Thus, the prey are directly available to seabirds. In the case of tropical systems, however, water clarity apparently makes prey (with the exception of volant flying fish, Exocetidae) too susceptible to epipelagic predators to allow them to aggregate in the upper water column during daylight. Although the tropical prey may aggregate at depth in association with vertical frontal boundaries, the results of this study provide additional evidence that yellowfin tuna, and thus their seabird commensals, prefer to search for prey in association with horizontal boundaries, i.e. the thermocline. 
The above would make sense when comparing ETP versus polar waters. Besides the stronger horizontal boundary found in the ETP current systems, the vertical boundary created by the front is orders of magnitude weaker (mean distance for $2^{\circ} \mathrm{C}$ change $=218 \mathrm{~km}$ ), on average, than at fronts in polar systems (cf Ainley \& Boekelheide 1983, Hunt \& Schneider 1987, Hunt et al. 1990, Hoefer 2000).

Acknowledgements. We thank the staff of the National Oceanic and Atmospheric Administration (NOAA) vessels 'Discoverer', 'Malcolm Baldrige', and 'Oceanographer', and of the UNOS vessel 'Endeavor'. Cruises were made possible by the Pacific Marine Environmental Laboratories, Atlantic Marine Oceanographic Laboratories, and Southwest Fisheries Science Center. Many persons assisted at sea; those who participated on repeated cruises were Steve Howell, Nina Karnovsky, Peter Pyle, and Sophie Webb. Paul Fiedler and Valerie Philbrick organized the oceanographic data collection on the 1998 cruise. Funding for L.B.S. and D.G.A. was by NSF grants OCE8515637, OCE8911125, and by National Geographic Society grants 3321-86, and 4106-89.

\section{LITERATURE CITED}

Ainley DG (1977) Feeding methods of seabirds: a comparison of tropical and polar communities in the eastern Pacific. In: Llano GA (ed) Adaptations in Antarctic ecosystems. Smithsonian Institution, Washington, DC

Ainley DG, Boekelheide RJ (1983) An ecological comparison of oceanic seabird communities of the South Pacific Ocean. Stud Avian Biol 8:2-23

Ando K, McPhaden JM (1991) Variability of surface layer hydrography in the tropical Pacific Ocean. J Geophys Res 102:23063-23077

Ashmole NP (1971) Sea bird ecology and the marine environment. In: Farner DS, King JR (eds) Avian biology, Vol. I. Academic Press, New York, p 223-286

Au DWK, Pitman RL (1986) Seabird interactions with dolphins and tuna in the eastern tropical Pacific. Condor 88: 304-317

Ballance LT, Pitman RL (1999) Feeding ecology of tropical seabirds. In: Adams N, Slotow R (eds) Bird life of South Africa. Proceedings of the 22nd International Ornithological Congress, Durban. Natural History Book Service, Johannesburg

Ballance LT, Pitman RL, Reilly SB (1997) Seabird community structure along a productivity gradient: importance of competition and energetic constraint. Ecology 78:1502-1518

Barber RT, Chavez FP (1986) Ocean variability in relation to living resources during the 1982-83 El Niño. Nature 319: 279-285

Barber RT, Chavez FP (1991) Regulation of primary productivity rate in the equatorial Pacific. Limnol Oceanogr 36: 1793-1802

Briggs KT, Dettman KF, Lewis DB, Tyler WB (1984) Phalarope feeding in relation to autumn upwelling off California. In: Nettleship DN, Sanger GA, Springer PF (eds) Marine birds: their feeding ecology and commercial fisheries relationships. Canadian Wildlife Service, Ottawa, p 51-62

Briggs KT, Tyler WG, Lewis DB, Carlson DR (1987) Bird communities at sea off California, 1975-1983. Stud Avian Biol $11: 1-74$
Brill RW, Block BA, Boggs CH, Bigelow KA, Freund EV, Marcinek DJ (1999) Horizontal movements and depth distribution of large adult yellowfin tuna (Thunnus albacares) near the Hawaiian Islands, recorded using ultrasonic telemetry: implications for the physiological ecology of pelagic fishes. Mar Biol 133:395-408

Brown RGB (1979) Seabirds of the Senegal upwelling and adjacent waters. Ibis 121:283-292

Brown RGB (1980) Seabirds as marine animals. In: Burger J, Olla BL, Winn HE (eds) Behavior of marine animals, Vol. 4. Plenum Press, New York, p 1-39

Brown RGB, Gaskin DE (1988) The pelagic ecology of the Grey and Red-necked Phalarope Phalaropus fulicarius and $P$. lobatus in the Bay of Fundy, eastern Canada. Ibis 130:234-250

Cadee GC (1981) Seabird observations between Rotterdam and the equatorial Atlantic. Ibis 117:339-356

CRC (Computer Resource Center) (1995) STATA reference manual: release 3.1, 6th edn. College Station, Texas

Crossin RS (1974) The storm-petrels (Hydrobatidae). In: King WB (ed) Pelagic studies of seabirds in the Central and Eastern Pacific Ocean. Smithsonian Institution, Washington, DC, p 154-203

Elphick CS, Hunt GL Jr (1993) Variations in the distributions of marine birds with water mass in the northern Bering Sea. Condor 95:33-44

Fiedler PC, Philbrick V, Chavez FP (1991) Oceanic upwelling and productivity in the eastern tropical Pacific. Limnol Oceanogr 36:1834-1850

Follestad A (1990) The pelagic distribution of Little Auk Alle alle in relation to a frontal system off central Norway, March/April 1988. Polar Res 8:23-28

Franks PJS (1992) Sink or swim: accumulation of biomass at fronts. Mar Ecol Prog Ser 82:1-12

Gould PJ (1974) Sooty Tern (Sterna fuscata). In: King WB (ed) Pelagic studies of seabirds in the central and eastern Pacific Ocean. Smithsonian Institution, Washington, DC, p 6-52

Gould PJ, Piatt JF (1993) Seabirds of the central North Pacific. In: Vermeer K, Briggs KT, Morgan KH, Siegel-Causey D (eds) The status, ecology, and conservation of marine birds of the North Pacific. (Spec Publ) Canadian Wildlife Service, Ottawa, Canada, p 27-38

Haney JC, McGillivary PA (1985) Midshelf fronts in the south Atlantic Bight and their influence on seabird distribution and seasonal abundance. Biol Oceanogr 3:401-430

Harrison NM, Hunt GL Jr, Cooney RT (1990) Front affecting the distribution of seabirds in the northern Bering Sea. Polar Res 8:29-31

Hoefer CJ (2000) Marine bird attraction to thermal fronts in the California Current system. Condor 102:423-427

Hunt GL Jr (1988) The distribution of seabirds at sea: physical and biological aspects of their marine environment. Current topics in avian biology. Proc 100th Deutsche Ornithologen-Gesellschaft (DO-G) International Meeting, Bonn, p 167-171

Hunt GL Jr (1990) The pelagic distribution of marine birds in a heterogeneous environment. Polar Res 8:43-54

Hunt GL Jr (1991a) Occurrence of polar seabirds at sea in relation to prey concentrations and oceanographic factors. Polar Res 10:553-559

Hunt GL Jr (1991b) Marine ecology of seabirds in polar oceans. Am Zool 31:131-142

Hunt GL Jr, Harrison NM (1990) Foraging habitat and prey taken by Least Auklets at King Island, Alaska. Mar Ecol Prog Ser 65:141-150

Hunt GL Jr, Schneider DC (1987) Scale-dependent processes 
in the physical and biological environment of marine birds. In: Croxall JP (ed) Seabirds: feeding ecology and role in marine ecosystems. Cambridge University Press, London, $\mathrm{p}$ 7-41

Hunt GL Jr, Harrison NM, Cooney T (1990) The influence of hydrographic structure and prey abundance on foraging of Least Auklets. Stud Avian Biol 14:7-22

Hunt GL Jr, Coyle KO, Hoffman S, Decker MB, Flint EN (1996) Foraging ecology of short-tailed shearwaters near the Pribilof Islands, Bering Sea. Mar Ecol Prog Ser 141: $1-11$

King WB (1974) Wedge-tailed Shearwater (Puffinus pacificus). In: King WB (ed) Pelagic studies of seabirds in the central and eastern Pacific Ocean. Smithsonian Institution, Washington, DC, p 53-95

Kleinbaum DG, Kupper LL, Muller KE (1988) Applied regression analysis and other multivariable methods. PWSKENT Publishing Company, Boston, MA

Murphy GI, Shomura RS (1972) Pre-exploitative abundance of tunas in the equatorial central Pacific. Fish Bull (Wash DC) 70:875-913

Oedekoven CS, Ainley DG, Spear LB (2001) Variable responses of seabirds to change in marine climate: California Current, 1985-1994. Mar Ecol Prog Ser 212:265-281

Olson DB, Backus RH (1985) The concentration of organisms at fronts: a cold-water fish and a warm-core Gulf Stream ring. J Mar Res 43:113-137

Olson RJ, Boggs CH (1986) Apex predation by yellowfin tuna: independent estimates from gastric evacuation and stomach contents, bioenergetics and cesium concentrations. Can J Fish Aquat Sci 43:1760-1775

Owen RW (1981) Fronts and eddies in the sea: mechanisms, interactions, and biological effects. In: Longhurst AR (ed) Analysis of marine ecosystems. Academic Press, San Francisco, CA, p 197-233

Pakhomov EA, McQuaid CD (1996) Distribution of surface zooplankton and seabirds across the Southern Ocean. Polar Biol 16:271-286

Pitman RL (1986) Atlas of seabird distribution and relative abundance in the eastern tropical Pacific. (Administration Rep No. LJ-86-02C). Southwest Fisheries Center, La Jolla, CA

Ribic CA, Ainley DG, Spear LB (1992) Effects of El Niño and La Niña on seabird assemblages in the equatorial Pacific. Mar Ecol Prog Ser 80:109-124

Reilly SB (1990) Seasonal changes in distribution and habitat

Editorial responsibility: Otto Kinne (Editor),

Oldendorf/Luhe, Germany differences among dolphins in the eastern tropical Pacific. Mar Ecol Prog Ser 66:1-11

Reilly SB, Fiedler PC (1994) Interannual variability of dolphin habitats in the eastern tropical Pacific. I: Research vessel surveys, 1986-1990. Fish Bull (Wash DC) 92:434-450

SAS Institute Inc (1985) SAS user's guide: statistics, version 5 edn. SAS Institute Inc, Cary, NC

Schneider DC (1982) Fronts and seabird aggregations in the southeast Bering Sea. Mar Ecol Prog Ser 10:101-103

Schneider DC (1990) Seabirds and fronts: a brief overview. Polar Res 8:17-21

Schneider DC, Harrison NM, Hunt GL Jr (1987) Variation in the occurrence of marine birds at fronts in the Bering Sea. Estuar Coast Shelf Sci 25:135-141

Schneider DC, Harrison NM, Hunt GL Jr (1990) Seabird diet at a front near the Pribilof Islands, Alaska. Stud Avian Biol 14:61-66

Seber GAF (1977) Linear regression analysis. John Wiley \& Sons, New York

Spear LB, Ainley DG (1997a) Flight behaviour of seabirds in relation to wind direction and wing morphology. Ibis 139: 221-233

Spear LB, Ainley DG (1997b) Flight speed of seabirds in relation to wind speed and direction. Ibis 139:234-251

Spear LB, Nur N, Ainley DG (1992) Estimating absolute densities of flying seabirds using analyses of relative movement. Auk 109:385-389

Spear LB, Ainley DG, Nur N, Howell SNG (1995) Population size and factors affecting at-sea distributions of four endangered procellariids in the tropical Pacific. Condor 97:613-638

Trenberth KE (1997) The definition of El Niño. J Am Meteorol Soc 78:2771-2777

Turner JM, Dagg MJ (1983) Vertical distributions of continental shelf zooplankton in stratified and isothermal waters. Biol Oceanogr 3:1-40

Veit RR (1995) Pelagic communities of seabirds in the South Atlantic Ocean. Ibis 137:1-10

Veit RR, Hunt GL Jr (1992) The spatial dispersion of seabirds near the South Orkney Islands and the Weddell-Scotia confluence. Polar Biol 11:637-641

Woods JK, Wiley RL, Briscoe MG (1977) Vertical circulation of fronts in the upper ocean. In: Angel M (ed) A voyage of discovery. Pergamon Press, Oxford, p 253-275

Wyrtki K (1966) Oceanography of the eastern equatorial Pacific Ocean. Oceanogr Mar Biol Annu Rev 4:33-68

Submitted: September 18, 2000; Accepted: January 15, 2001 Proofs received from author(s): August 15, 2001 